\title{
Control of construction projects using the Earned Value Method - case study
}

https://doi.org/10.1515/eng-2019-0020

Received Feb 10, 2019; accepted Apr 10, 2019

\begin{abstract}
Planning, controlling, monitoring progress are key management functions for effective implementation of construction projects. Commonly used instruments enabling performance of these functions include schedules and budgets, often in the form of a cost estimate. They are created at the initial planning stage to monitor and control cost and time deviations. Moreover, popular monitoring techniques are, for example, observation of milestones and comparative analysis of actual versus planned costs. This article presents a work progress control tool - the Earned Value Method (EVM) - which, despite its benefits, remains relatively unused in construction projects. The impact of the planning phase on the results obtained during the monitoring and control phase when utilizing EVM is discussed. This case study provides practical examples of using EVM in the implementation of construction projects and with the use of computer software. The novelty of the article results from the introduction of additional sensitivity analysis illustrating the impact of factors, such as an increase in costs or a change in delivery dates to the course of deviation curves. Use of sensitivity analysis in relation to the results of the CPI and SPI calculations affords combining control of costs and time with risk monitoring in the project. The findings reveal significant benefits in using EVM to implement construction projects but also highlight some important limitations.
\end{abstract}

Keywords: earned value method (EVM), cost control, schedule control

\footnotetext{
${ }^{\star}$ Corresponding Author: Krystyna Araszkiewicz: West Pomeranian University of Technology, Faculty of Civil Engineering and Architecture, Aleja Piastów 50, 70-311 Szczecin, Poland; Email: krystyna.araszkiewicz@zut.edu.pl

Magdalena Bochenek: West Pomeranian University of Technology, Faculty of Civil Engineering and Architecture, Aleja Piastów 50, 70-311 Szczecin, Poland; Email:magdalena.bochenek@zut.edu.pl
}

\section{Introduction}

Building projects are undertaken under high-risk conditions and are fraught with a high probability of change during the construction stage. The risk is associated with significant potential financial consequences that may arise, for example, from a delay in completion of the work. Thus, controlling and monitoring progress during the construction and investment process require systematic collection of information regarding the volatility of risk factors vis-avis financing and timely execution. This necessity constitutes a major challenge for project managers. As construction projects become increasingly technologically complex, many subcontractors and suppliers have to be simultaneously involved in project implementation. Consequently, ongoing control of costs and compliance with the schedule can become a difficult management task [1].

What is even more difficult under these conditions is monitoring the construction process: this requires systematic collection of information to analyze a project's progress, budget and costs, schedule, and implementation risks. These efforts are undertaken to make decisions that ensure compliance with the established criteria. Traditional means of control are based on comparing (1) planned costs with actual costs incurred and (2) time planned for each task within the project versus the actual time incurred. Results of this comparison generally are insufficient to meet the scope of information necessary for optimal decision making. This is especially so when there are measures that have to be taken to prevent delays and over-budget expenditures.

A well-known method that affords collecting and analyzing comprehensive amounts of information about a project's progress is the Earned Value Method (EVM). EVM is well known and has been the subject of research aimed at its further development. An in-depth overview of literature related to EVM and its application was previously undertaken [2].

Despite the many benefits of EVM, it is not widely used in the construction services sector in Poland. By presenting an example of an application of EVM in construction projects implemented in Poland, the article aims to en-

๑ Open Access. (C) 2019 K. Araszkiewicz and M. Bochenek, published by De Gruyter. 
hance knowledge about the capabilities and implementation aspects of EVM in relation to execution of construction projects. A case study is presented, which is initially preceded by a discussion of key findings taken from the foregoing literature overview.

Case study is a qualitative research method. It affords a thorough analysis of a given phenomenon. Accordingly, it serves as an adequate method for examining the conditions and results of using EVM in construction projects. Reviewed literature was taken from the Google Scholar and Scopus databases using the following keywords: EVM and monitoring of construction projects. Publications in 20112019 were included in the analysis.

\subsection{Earned Value Method}

EVM provides information about both the actual implementation progress and costs of a project. The calculated indicators also allow for proposing further steps in project development. Owing to observation of trends in the systematically recorded implementation progress, calculating the final cost and completion date of the project are possible [3, 4].

The three core values used in EVM are Planned Value (PV), Earned Value (EV), and Actual Cost (AC). PV represents the planned cost of the material scope of scheduled work (the "base plan"). EV embodies the planned cost of the completed material scope of work (measured by the material progress at the time of the audit). AC reflects the literal cost of the tasks performed at a given period in time. Another piece of information needed to monitor deviations is the planned duration of the project. $\mathrm{PV}, \mathrm{EV}$, and AC curves are delineated in a time-cost space [5]. They are the basis for calculating subsequent indicators for assessment of deviations from the budget and schedule and for the forecasting of the further course of project implementation. These indicators entail Schedule Performance Index (SPI) and Cost Performance Index (CPI), Schedule Variance (SV) and Cost Variance (CV), Estimated Time at Completion (ETTC), To Complete Performance Index (BAC), and TCPI Schedule (OD) [5, 6].

Indicators used in EVM are based on cost information. EVM, in its classic form, does not include overhead, but overhead may constitute a significant part of a construction project's cost structure. One way to include overhead within EVM is to allocate the number of staff and equipment used to a project [5]. Another extension of the method is the concept of Earned Schedule (ES). Such information provides the time in which, according to the planned schedule, the value at the given moment (EV at actual time ET) should have been reached.

Another modification to EVM is Earned Duration Management. The main indicators of this method are based on measurement of Total Planned Duration (TPD), Total Earned Duration (TED), and Earned Duration (ED) [7]. A recent study proposed, utilizing this approach, monitoring a project against the plan with use of statistical control charts in which the project performance indicators are plotted over time.

A new approach, using ex ante control charts in two stages, has been developed. In the first stage, the analysis is conducted in view of the time limits of the project, by taking into account its specific features (e.g., the data collection method, sample size per each review period, project time span, and acceptable deviations). In the second stage of the plan and the resulting limitations are confronted backwards with the actual project progress [8].

Fuzzy estimates have also been introduced into EVM in forecasting the time and cost of project completion. Such effort is directed at improving the accuracy and reliability of the results of such forecasts $[9,10]$. A fuzzy approach is proposed for planning, as it enables inclusion of the uncertainty aspect of the planned activities and simultaneous use of crashing and fast tracking in the project schedule [11-13]. Research efforts are currently focused on finding ways to improve the accuracy of forecasting within $\operatorname{EVM}[14,15]$. The possibility of monitoring the stability of EVM forecasting methods, including the stability of the cost performance index (CPI) as a leading indicator of future performance, is being explored $[16,17]$.

In terms of management needs, the reporting method is an important component in controlling and monitoring the system. It should be designed so that collecting progress and cost data is optimized. The two main reporting standards of EVM, widely used in projects, are as follows:

- CPR (Cost Performance Report): a report on the project cost, designed for expensive, technologically-complex projects. It is forecasted per work package and cost account level and consists of five parts:

information about earned value as per Work Breakdown Structure (WBS)

$\square$ information on earned value as per functional type (project, implementation, maintenance, etc.)

information on changes to the baseline

information on actual and planned employment levels 
Table 1: The dependencies between SPI and CPI values, based on: $[1,3]$

\begin{tabular}{cccc}
\hline SPI and $\mathrm{CPI}$ & $\mathrm{SPI}<1,0$ & $\mathrm{SPI}=1,0$ & $\mathrm{SPI}>1,0$ \\
\hline $\mathrm{CPI}<1,0$ & $\begin{array}{c}\text { over budget, behind schedule } \\
\text { on budget, behind schedule } \\
\text { under budget, behind } \\
\text { schedule }\end{array}$ & $\begin{array}{c}\text { over budget, on schedule } \\
\text { on budget, on schedule } \\
\text { under budget, on schedule }\end{array}$ & $\begin{array}{c}\text { over budget, ahead of schedule } \\
\text { on budget, ahead of schedule } \\
\text { under budget, ahead of schedule }\end{array}$ \\
\hline
\end{tabular}

explanation of variance analysis

- C/SSR (Cost/Schedule Status Report): a report involving cost /schedule status; it is designed for less expensive and simpler projects (being a simplified version of $\mathrm{CPR}$ ). The report can be used at any level of the project. It consists of two parts:

information about earned value as per WBS

explanation of variance analysis.

Collection of data and reporting as per EVM requires a considerable amount of time and creates additional costs for project monitoring. Indeed, given the large amount of information required and the need for a careful preparation of the output data, as well as the requisite of reliable collection of information in the control process, use of EVM is still associated with additional management costs [18].

One of the current directions of research involving EVM is integration of EVM with the Building Information Modelling (BIM) method [19]. The proposed method of increasing control efficiency entails monitoring the material and cost progress of a project using the BIM 5D model with the support of the EVM platform. This integrated cost and time management system includes four modules: time and cost estimating, scheduling, visualization, and EVM. A test of the system executed in an actual construction enterprise revealed numerous advantages of integration of the information collected within the model and within EVM [20].

The next step related to development of EVM in association with trends in the development of new tools for management of construction processes using digital technologies is the concept of BIM-based Visual Risk critical path (BIM-VRcp). BIM-VRcp combines time and cost control and monitoring with the risk in construction projects. The application of BIM-VRcp allows generation of seven value curves obtained for seven risk levels (defined as critical paths in the project schedule) [21].

Because risk is an issue with which EVM is directly related, there are increasingly more attempts to integrate tools used in risk management and EVM [22-24]. One example involves combining EVM with a quantitative risk analysis tool- the Monte Carlo simulation [25]. Another example is utilizing two new indicators as part of the integration of EVM with project risk management tools: the risk baseline and buffers [26].

Another interesting direction of development for EVM is complementing the scope of control and monitoring by including quality. One such concept is Earned Quality Value Management (EQVM). It is a tool affording integration within reporting of cost and time with quality in accordance with the classical model of the 'golden triangle' [27]. One other approach, based on the use of a matrix (SPICPI two-dimensional matrix relational charts), entails illustrating the progress of a project to address the needs of the project team so that delays can be prevented [28].

This current study presents an application of the classical version of EVM. This particular focus was adopted because this method is not widely applied in Polish construction projects. Therefore, attention should be paid to the results of its classical application in projects implemented in the conditions of the Polish construction market.

A flowchart of the algorithm for EV analysis is shown in Figure 1.

The dependencies between the main indicators in EVM (SPI and CPI values) are shown in Table 1

\section{Case study}

The focal building is a three-storey multi-family building. The underground floor houses garages, utility rooms, and storage rooms for residents. The building is constructed on a foundation plate, with walls made from blocks and reinforced concrete. The roof is a traditional purlin and rafter structure with ceramic roof tiles.

The contractor began work in November 2010, resigned in October 2011, and left the construction site without its completion. The work performed by the first contractor was as follows:

- December 2010, partly January and February 2011: no work was undertaken due to adverse weather conditions 


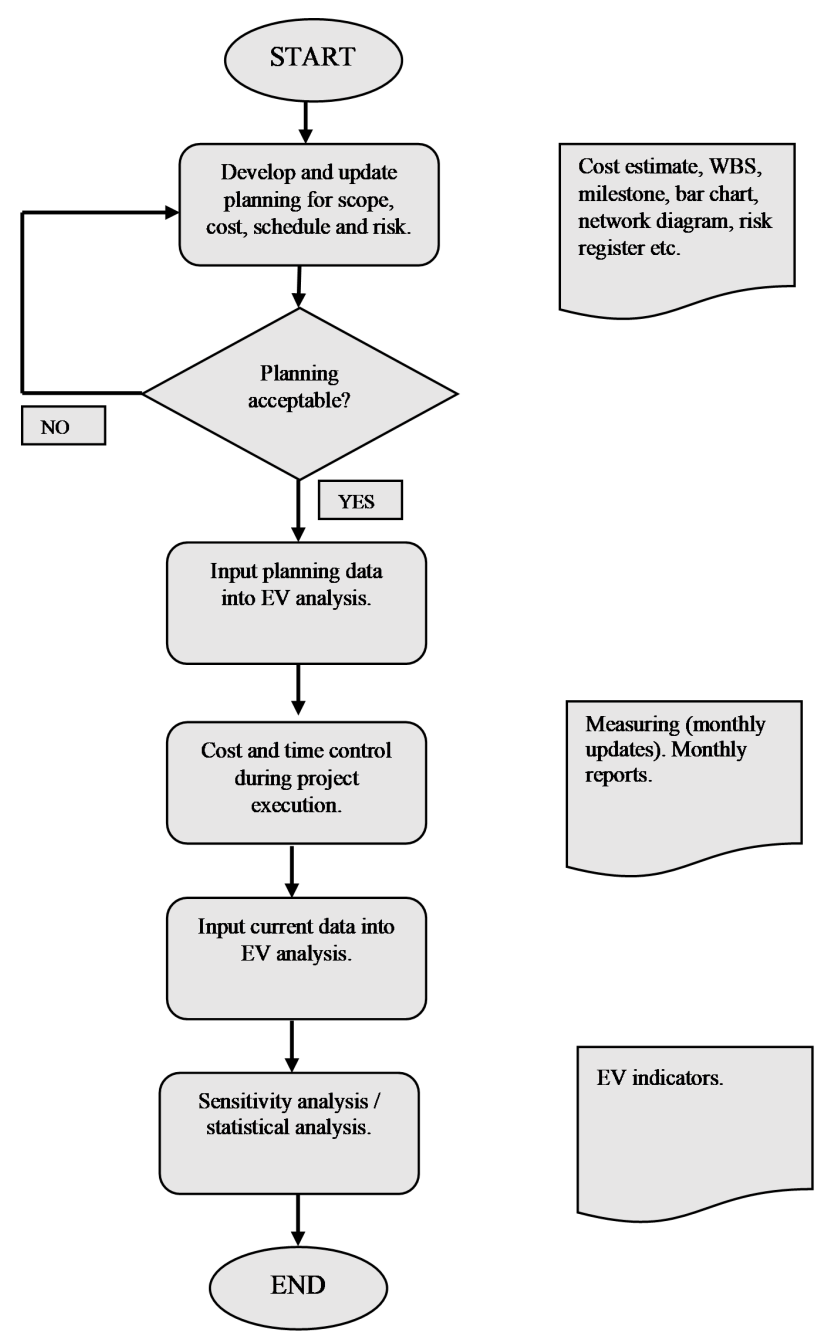

Figure 1: Flowchart of earned value analysis [authors' data]

- January - February 2011: wide excavation under the building was done

- February 2011: lean concrete was poured and insulation of the foundation plate was laid

- March 2011: reinforced concrete of the foundation plate was poured

- March-April 2011:reinforced concrete poured for the walls and columns of the underground floor

- May 2011: work related to implementation of plumbing installation and connection of water supply was performed

- June 2011: reinforced concrete was poured for the slab above the garage and the staircase

- July 2011: load-bearing walls of the first floor and reinforced concrete of the first-floor slab was laid, and installation of sewage and rainwater drainage system in the garage was started
- August 2011: load-bearing walls of the 1st floor, reinforced concrete of the slab above the first floor, and reinforced concrete of columns and staircases of the attic were laid

- September 2011: construction work was stopped due to the poor financial situation of the contractor

- October 2011: reinforced concrete of substrings and slab over the attic were poured.

In December 2011, a contract was signed with a second contractor. The work not completed by the first contractor (insulation of foundation walls, backfilling, roof, joinery and doors, partitions, plasterwork, floors, insulation, forging and plumbing work, painting, and facades) were now entrusted to the second. Because of the winter season, work was agreed to begin on $10^{\text {th }}$ March 2012, and the completion date was set for $31^{\text {st }}$ July 2012. A fixed remuneration for the contractor was agreed on; settlement was to take place on the basis of partial invoices.

Work performed by another contractor was as follows:

- March 2012: vertical insulation of basement walls, construction of partitions, and sanitary and electrical installations were completed

- April 2012:partition walls bricklaying, backfilling around the building and garage driveway, interior plasterwork, and plumbing and electrical installations were completed

- May 2012: joinery and doors, partition walls bricklaying, interior plasterwork, foundations and floors, and sanitary and electrical installations were done

- June 2012: foundations and floors, insulation of the attic, railings and roofing, facade work, and sanitary and electric installations were completed

- July, August 2012: insulation of the attic, door joinery, railings and roofing, painting, facade works, arrangement of area outside the building, and sanitary and electrical installations were performed.

In the course of the work performed, monthly reports were created on the basis of the updated schedule, and the Earned Value analysis was performed. The results for PV, $\mathrm{AC}$, and EV are summarized in Figure 2.

Indicators of construction implementation of the first few months (Figure 1) clearly indicate that the work began with a slight delay. From June 2011 to September 2011, the PV curve runs parallel to the EV curve; this indicates that the scope of the work is per the plan, but implemented with the noted delay. From the November 2011, the difference between $P V$ and $E V$ increases, which points to the risk of increasing delays. 


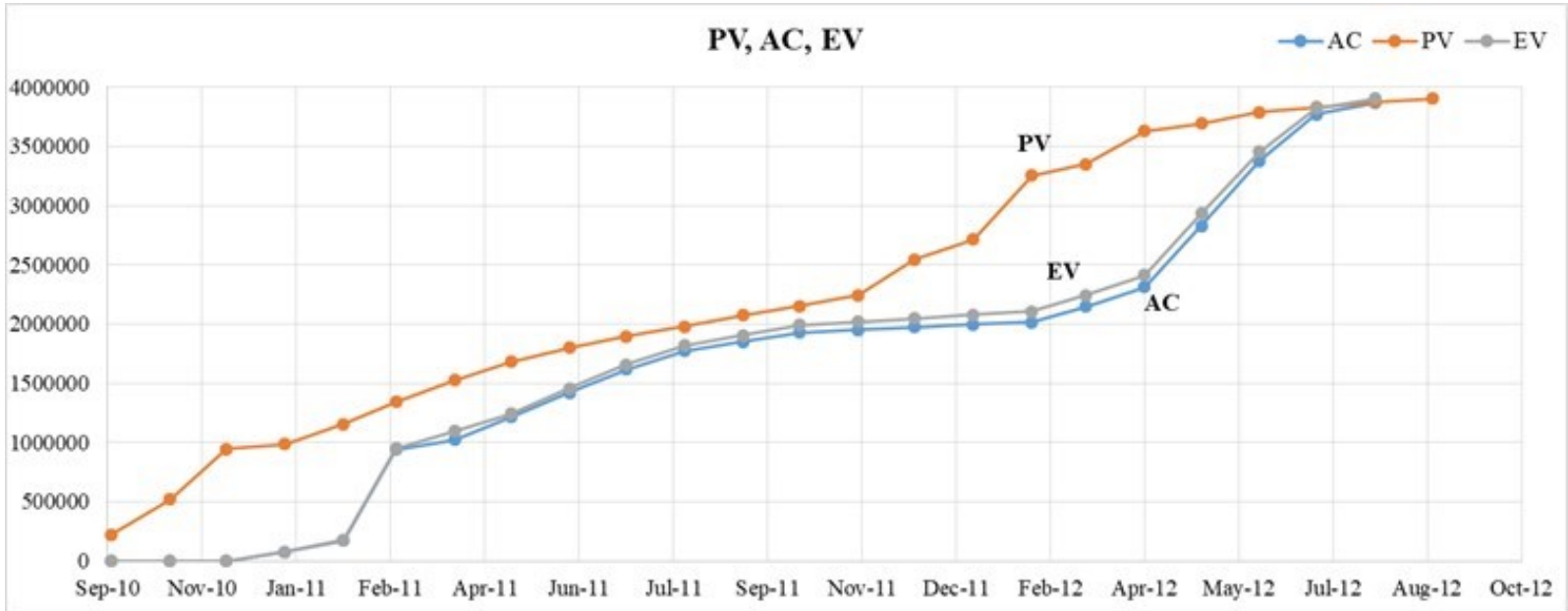

Figure 2: PV, AC, EV [authors' data]

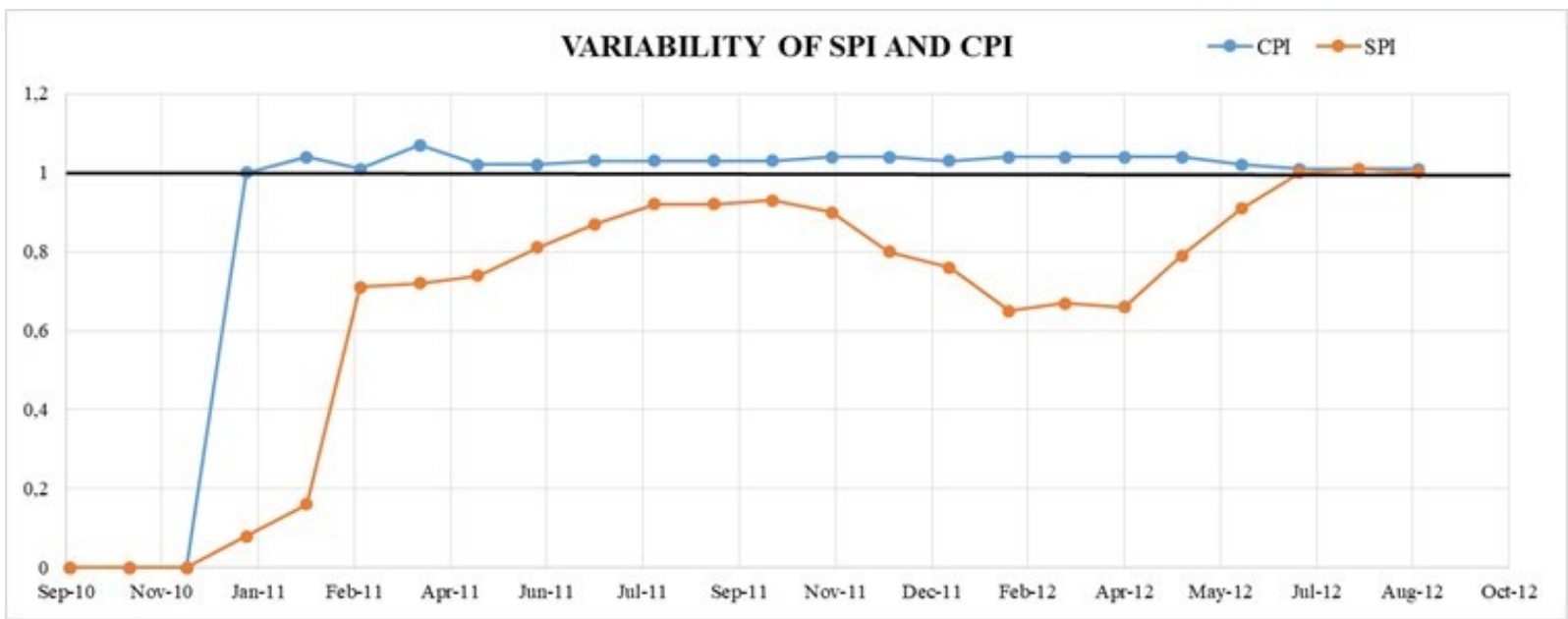

Figure 3: Variability of SPI and CPI [authors' data]

The final cost of the project was 3,868,319.55 PLN. This metric was lower by as much as 37,031.23 PLN from the initially adopted cost of the work (BAC from October 2010). Two especially useful indicators obtained owing to EVM, are the Cost Performance Index (CPI) and Schedule Performance Index (SPI). The positive CPI and SPI values imply that the implementation, both in terms of cost and schedule, was better than planned, while the negative values infer that the planned values were not achieved. The curves of these two values during the implementation of the project are shown in Figure 3.

The value of SPI indicates that until March 2011, only $71 \%$ of the planned work was completed. Between March 2011 and February 2012, the Schedule Performance Index decreased from 0.71 to 0.65 , which means that only $65 \%$ of the planned work had been completed. Indeed, the CPI stabilized around 1.03. A value of CPI $>1$ is considered a satisfactory situation. The SPI was approximately 0.08 in January 2011 and had been in a range between 1.0 and 0.16 during the last one and a half year. A value of SPI $<1$ suggests that the project is behind schedule. The SPI had been increasing since March 2011 owing to improvement in the project's progress.

Another part of the project entailed road works (access roads to an industrial hall, parking lots, and sidewalks). This part of the project was planned for a four-month period. However, the actual duration of work exceeded one year. The construction project was planned from June 2006 to September 2006. The contractor began work in August 2006 and then the construction work was stopped for three months (December 2006-February 2007). Due to the extensive delay, the second contractor was hired to improve execution of the project. He began the work on March 2007 and finished his commission on April 2007. The last two 


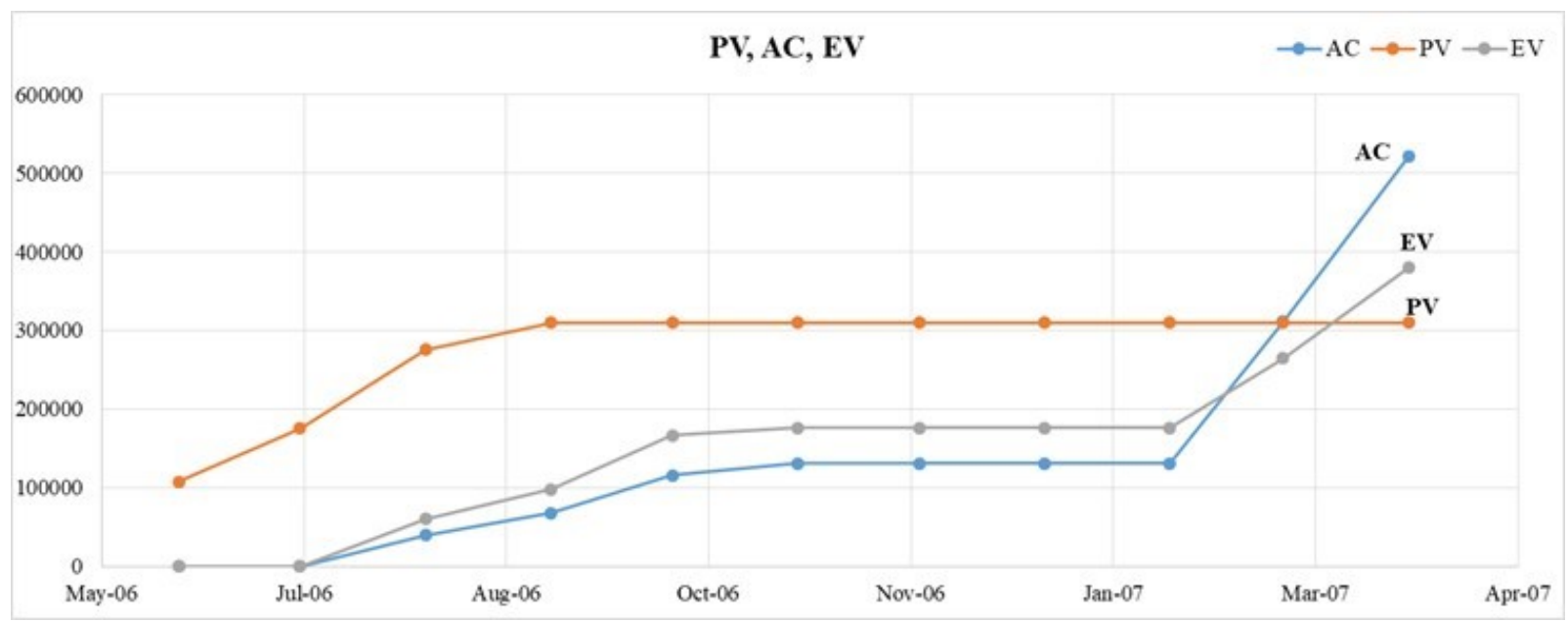

Figure 4: PV, AC, EV [authors' data]

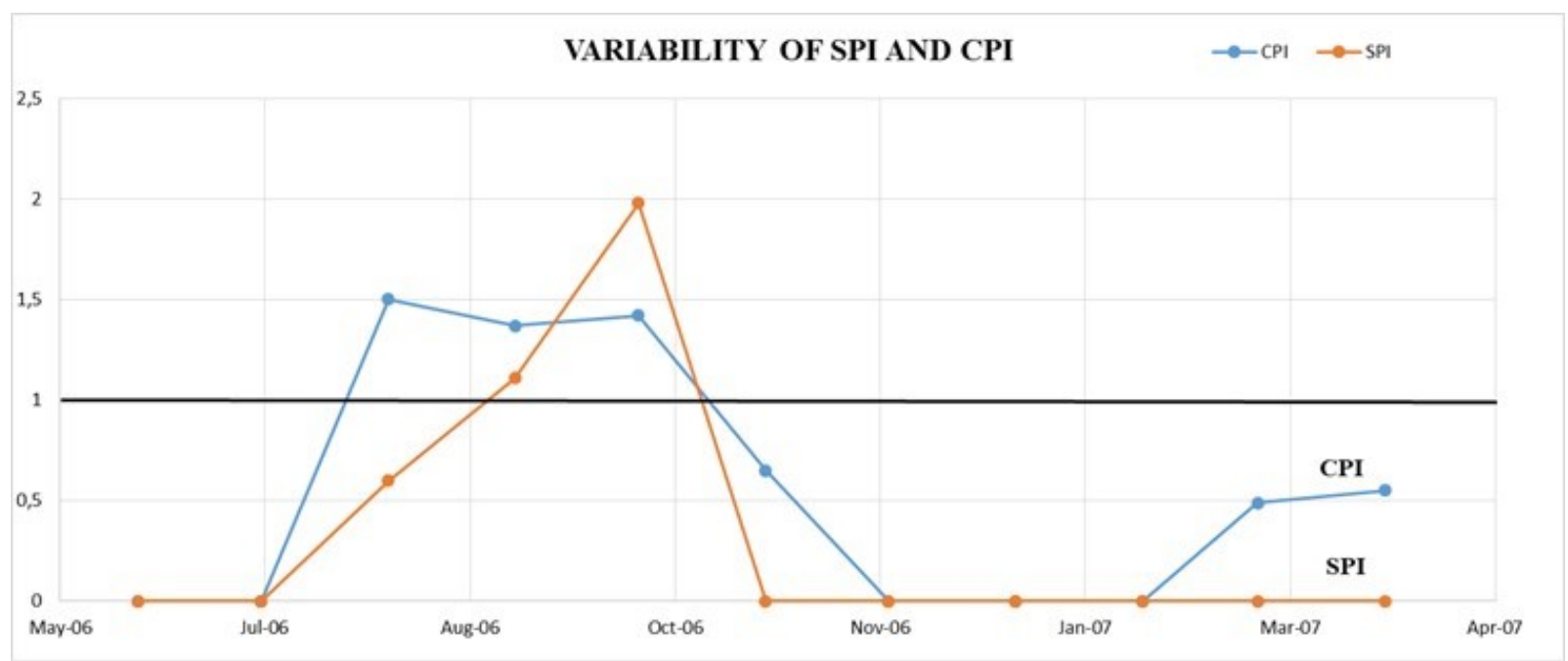

Figure 5: Variability of SPI and CPI [authors' data]

months both contractors worked together. In the course of the work carried out, monthly reports were created on the basis of the updated schedule, and the Earned Value analysis was carried out. Figure 4 shows a summary of the results obtained for PV, AC, and EV.

Indicators of construction implementation of the first few months (Figure 4) reveal that the work began with a two-months delay. The final cost of the project was 521000 PLN, and it was higher by as much as 211100 PLN from the initially-adopted cost of the work (BAC from June 2006). The higher cost was a result of an underestimation of the investment duration, costs of some tasks, and major difficulties of finding subcontractors (owing to the construction market during the period under review).

The variability of the Cost Performance Index (CPI) and the Schedule Performance Index (SPI) from the com- mencement of the project up to April 2007 is shown in Figure 5.

The value of SPI indicates that until August 2006, only $60 \%$ of the planned work was completed. Between August 2006 and April 2007, the Schedule Performance Index decreased from 0.6 to 0 , which means that $0 \%$ of the planned work had been completed. The CPI stabilized around 1.4 for three months. A value of CPI $>1$ is considered a favorable outcome; unfortunately, the first contractor stopped work, so the second contractor was hired. In the last two months, the CPI was approximately 0.5 , which is less than 1.0. The SPI was around 0.6 in August 2006 and had been in the range between 1.11 and 1.98 in September and October. A value of SPI < 1 suggests that the project is behind schedule. In the last six months, the SPI was 0 because 


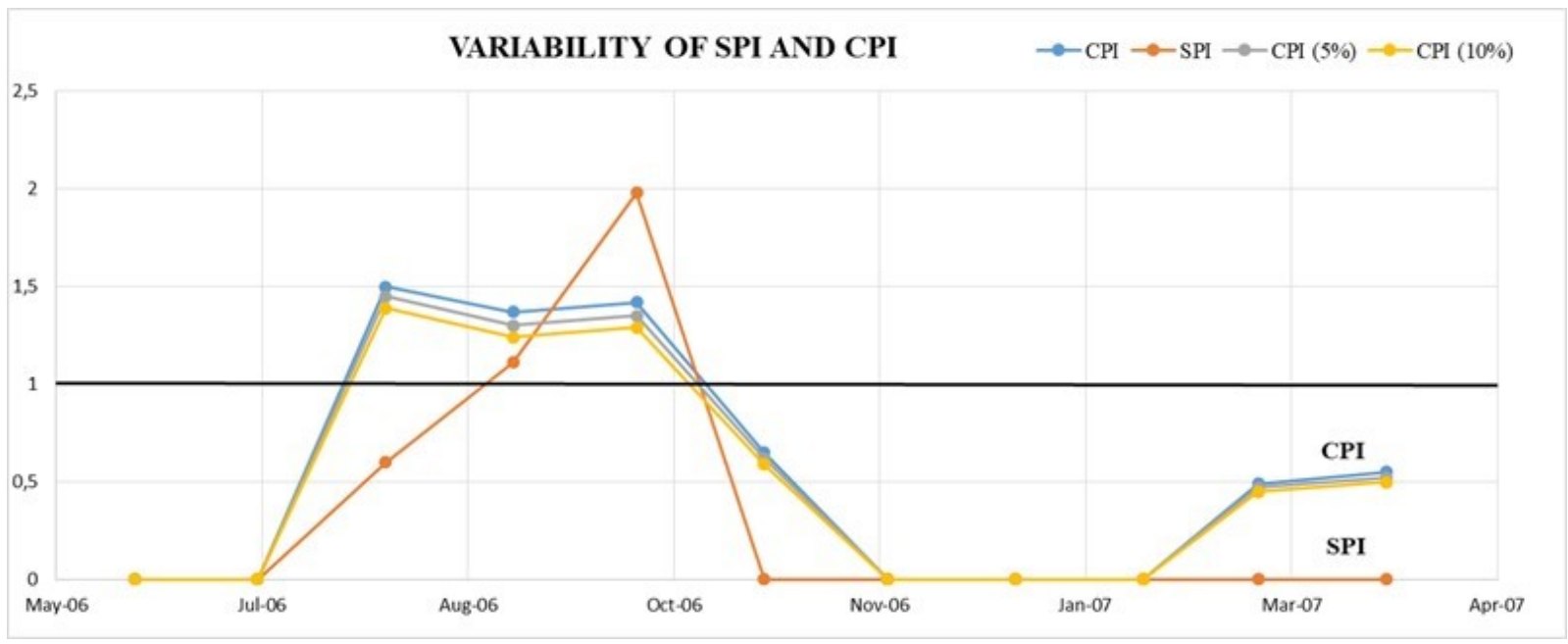

Figure 6: Variability of SPI and CPI [authors' data]

no work was planned. As shown in Table 1, the analyzed project was over budget and behind schedule.

A current analysis of EVM indicators shows how the actual state of project implementation deviates from the original one. The work was delayed from the very start; not only was it impossible to make up for the delay, but the delay was even further increased.

On the basis of two examples, the Earned Value Method seems logical for use only for projects of a year or longer. Only then the tendency necessary to determine the indicators related to project completion may develop.

A sensitivity analysis was conducted for the second investment. The starting point was the base scenario. The current cost (AC) was changed by $+5 \%$ and by $+10 \%$, and the implementation time was extended by $+5 \%$ and by $+10 \%$. Other factors remained unchanged. This allowed finding an answer to the question of what would happen to a given project if the variable assumed in the analysis was different (Figure 6).

In the case of a change in the current cost (AC) by $+5 \%$ and by $+10 \%$, the SPI parameter did not change, and the CPI changes were insignificant. Changes in CPI coefficient are shown in Table 2.

In the case of the implementation of the SPI parameter, both the SPI and CPI parameters changed (Figure 7). Changes in SPI and CPI coefficients are shown in Table 3.

Owing to the sensitivity analysis through individual changes, new values of SPI and CPI were obtained. The diagrams of the SPI and CPI dependence on the factors being changed were created.

Of the two factors studied, the most sensitive data were the time of completion; these should be estimated in the most accurate and probable way.
Table 2: Changes of CPI values [authors' data]

\begin{tabular}{cccc}
\hline Month & CPI & $\begin{array}{c}\text { CPI } \\
(\mathrm{AC}+5 \%)\end{array}$ & $\begin{array}{c}\text { CPI } \\
(\mathrm{AC}+10 \%)\end{array}$ \\
\hline $06.2006-07.2006$ & 0 & 0 & 0 \\
08.2006 & 1,5 & 1,45 & 1,39 \\
09.2006 & 1,37 & 1,3 & 1,24 \\
10.2006 & 1,42 & 1,35 & 1,29 \\
11.2006 & 0,65 & 0,62 & 0,59 \\
$12.2006-01.2007$ & 0 & 0 & 0 \\
-02.2007 & & & \\
03.2007 & 0,49 & 0,47 & 0,45 \\
04.2007 & 0,55 & 0,52 & 0,5 \\
\hline
\end{tabular}

\section{Summary}

Taking into account the planned and literal duration of the investment (about one year), the project control and calculation of EVM indicators were performed at one-month intervals. Per the four-month construction (second case study), a monthly analysis would not be recommended, because any corrective action may be too late. In both cases, progress was determined on the basis of weekly checks concerning the actual work performed. The cost of the planned work was estimated using tender cost estimates submitted before the investment began. The actual cost incurred was established on the basis of invoices paid. The project was performed by subcontractors; no employees were hired. In both cases, the actual cost incurred was anticipated to be the same as the cost provided by the subcontractor in the tender estimates. Subcontractor estimates were based on lump-sum contracts which stipulated penal- 
Table 3: Changes of SPI and CPI values [authors' data]

\begin{tabular}{ccccccc}
\hline Month & CPI & $\begin{array}{c}\text { CPI } \\
\text { (duration+5\%) }\end{array}$ & $\begin{array}{c}\text { CPI } \\
\text { (duration+10\%) }\end{array}$ & SPI & $\begin{array}{c}\text { SPI } \\
\text { (duration+5\%) }\end{array}$ & $\begin{array}{c}\text { SPI } \\
\text { (duration+10\%) }\end{array}$ \\
\hline 06.2006 & 0 & 0 & 0 & 0 & 0 & 0 \\
07.2006 & 0 & 0 & 0 & 0 & 0 & 0 \\
08.2006 & 1,5 & 1,80 & 2,20 & 0,6 & 0,72 & 0,84 \\
09.2006 & 1,37 & 1,91 & 2,46 & 1,11 & 1,56 & 2,01 \\
10.2006 & 1,42 & 1,74 & 2,06 & 1,98 & 2,43 & 2,87 \\
11.2006 & 0,65 & 0,91 & 1,17 & 0 & 0 & 0 \\
12.2006 & 0 & 0 & 0 & 0 & 0 & 0 \\
01.2007 & 0 & 0 & 0 & 0 & 0 & 0 \\
02.2007 & 0 & 0 & 0 & 0 & 0 & 0 \\
03.2007 & 0,49 & 0,58 & 0,65 & 0 & 0 & 0 \\
04.2007 & 0,55 & 0,64 & 0,73 & 0 & 0 & 0 \\
\hline
\end{tabular}

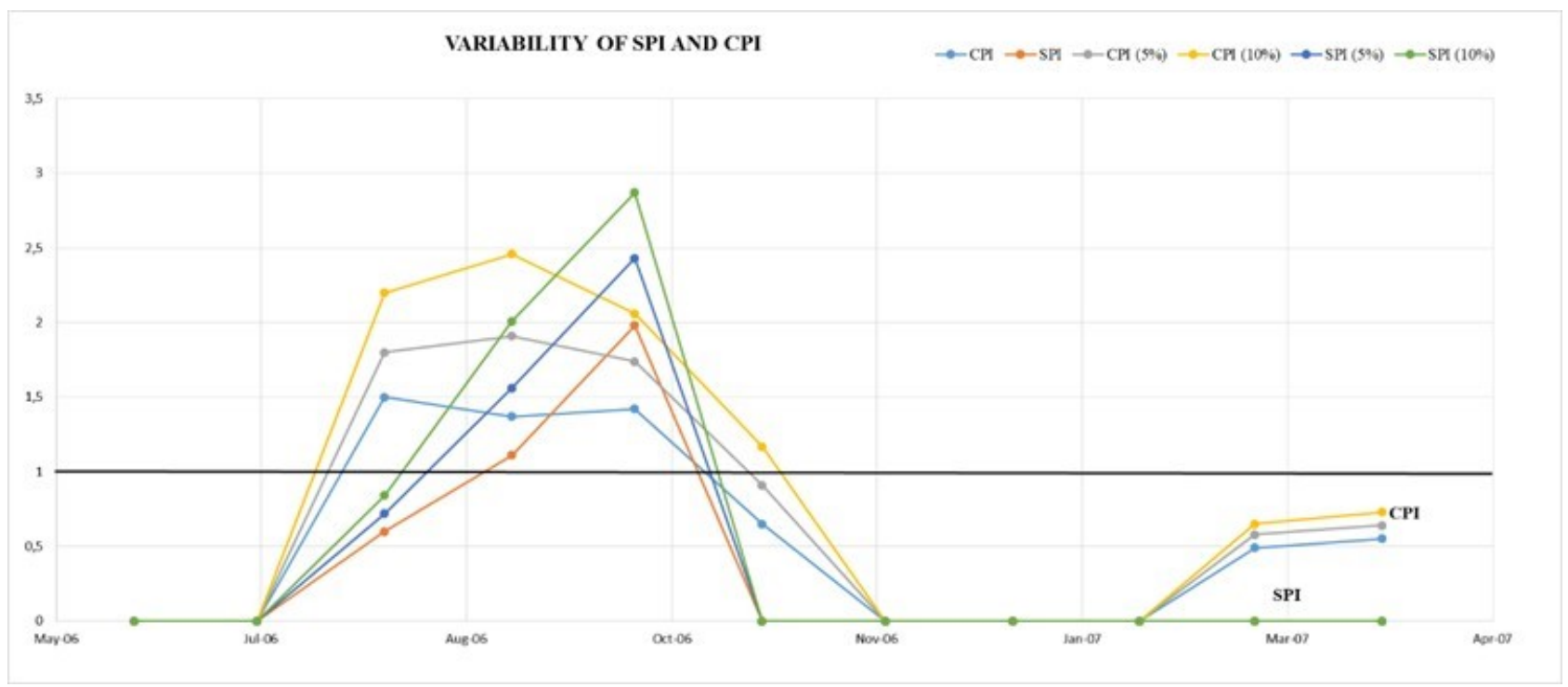

Figure 7: Variability of SPI and CPI [authors' data]

ties for failure to comply with the work schedule $(0.3 \%$ of the contract value for each day of delay) and a fine for withdrawal from the contract (10\% of the contract price). Unfortunately, in both cases, the initially-selected subcontractor resigned and left the site mainly due to financial problems. In the second case study, the pricing of subsequent subcontractors was, unfortunately, higher than the estimate, while the contractual penalties were almost impossible to recover.

Analyzing both cases, the following conclusions can be drawn regarding the use of EVM in Polish construction projects:

- based on several parameters (PV, EV, AC), one can quickly assess the actual project status
- EVM allows an early detection for errors, as well as immediate action to prevent the emergence of subsequent faults

- reliability of the results largely depends on the persons involved in project planning and monitoring

- EVM is best suited for projects that last more than a year

- for projects lasting less than a year, more frequent project auditing and regular determination of earned value (EV) are recommended

- there are possibilities of distortion of the EVM indicators (e.g., performing non-critical tasks)

- future project costs can be estimated even with little project progress 
- a simple analysis of the CPI and SPI indicators facilitates project management.

In the case of projects in which external subcontractors and suppliers are involved, an estimation of the actual cost (AC) can be based on actually performed work and invoices issued by the subcontractor for a given settlement period. However, in the case of large construction projects with subcontractors' own work force, detailed cost determination may be more difficult. Therefore, planning, for example, a financial data flow management system is advisable. The settlement of general construction costs may also be a problem. The reliability of the results obtained largely depends on a detailed and accurate determination of the progress of the work and properly prepared base plans.

The novelty of the article results from the introduction of additional analysis illustrating the impact of factors, such as an increase in costs or a change in delivery dates to the course of deviation curves. Use of sensitivity analysis in relation to the results of the CPI and SPI calculations affords combining control and monitoring of costs and time with risk monitoring in the project. Using a combination of analysis of EV method indicators and sensitivity analysis during project implementation - when its course and dates, as well as completion costs, are forecasted - facilitates identifying events that may increase deviations from the budget and schedule. As such, more effective preventive actions are possible. The combination of risk analysis during the implementation of the project with EVM analysis is an interesting direction for further research, which may be an extension of the issue addressed in this article.

\section{References}

[1] Połoński M., Komendarek P., Bieżąca kontrola kosztów realizacji obiektu budowlanego metodą Earned Value, Metody ilościowe w badaniach ekonomicznych, 2011, XII/2, 279-290

[2] Willems L. L., Vanhoucke M., Classification of articles and journals on project control and earned value management, International Journal of Project Management, 2015, 33(7), 1610-1634

[3] Połoński M., Kontrola kosztów realizacji obiektu budowlanego metodą Earned Value, Inżynieria przedsięwzięć budowlanych Rekomendowane metody i techniki, SIPB KILiW PAN, 2015, 81125

[4] Czarnigowska A., Sobotka A., Metoda planowania i kontrolowania realizacji przedsięwzięć budowlanych: studium przypadku, Górnictwo i Geoinżynieria, 2015, 35, 37-56

[5] Aminian V., Nejad A., Mortaji S., Bagherpour M., A modified earned value management using activity based costing, Journal of Project Management, 2016, 1(2), 41-54
[6] Dziadosz A., Kapliński O., Rejment M., Użyteczność i zakres stosowania metody Earned Value Management przy realizacji kontraktów budowlanych, Budownictwo i Architektura, 2014, 13(4), 257-364

[7] de Andrade P. A., Martens A., Vanhoucke M., Using real project schedule data to compare earned schedule and earned duration management project time forecasting capabilities, Automation in Construction, 2019, 99, 68-78

[8] Mortaji S. T. H., Noori S., Noorossana R., Bagherpour M., An ex ante control chart for project monitoring using earned duration management observations, Journal of Industrial Engineering International, 2018, 14(4), 793-806

[9] Naeni L. M., Shadrokh S., Salehipour A., A fuzzy approach for the earned value management, International Journal of Project Management, 2011, 29(6), 764-772

[10] Feylizadeh M., Hendalianpour A., Bagherpour M., A fuzzy neural network to estimate at completion costs of construction projects, International Journal of Industrial Engineering Computations, 2012, 3(3), 477-484

[11] Feylizadeh M. R., Mahmoudi A., Bagherpour M., Li D. F., Project crashing using a fuzzy multi-objective model considering time, cost, quality and risk under fast tracking technique: A case study, Journal of Intelligent \& Fuzzy Systems, 2018, 1-19

[12] Mortaji S. T. H., Bagherpour M., Noori S., Fuzzy earned value management using LR fuzzy numbers, Journal of Intelligent \& Fuzzy Systems, 2013, 24(2), 323-332

[13] Salari M., Bagherpour M., Kamyabniya A., Fuzzy extended earned value management: A novel perspective, Journal of Intelligent \& Fuzzy Systems, 2014, 27(3), 1393-1406

[14] Chen H. L., Chen W. T., Lin Y. L., Earned value project management: Improving the predictive power of planned value, International Journal of Project Management, 2016, 34(1), 22-29

[15] Batselier J., Vanhoucke M., Improving project forecast accuracy by integrating earned value management with exponential smoothing and reference class forecasting, International Journal of Project Management, 2017, 35(1), 28-43

[16] Wauters M., Vanhoucke M., Study of the stability of earned value management forecasting, Journal of Construction Engineering and Management, 2014, 141(4), 04014086

[17] Kim B. C., Probabilistic evaluation of cost performance stability in earned value management, Journal of Management in Engineering, 2015, 32(1), 04015025

[18] Christensen D. S., The costs and benefits of the earned value management process, Journal of Parametrics, 1998, 18(2), 1-16

[19] Zapata P., Cárdenas C., Lozano N., Building Information Modeling 5D and Earned Value Management methodologies integration through a computational tool, Revista Ingeniería de Construcción, 2019, 33(3), 263-278

[20] Jrade A., Lessard J., An integrated BIM system to track the time and cost of construction projects: a case study, Journal of Construction Engineering, 2015, http://dx.doi.org/10.1155/2015/ 579486

[21] Chang H. K., Yu W. D., Cheng S. T., A Risk-based Critical Path Scheduling Method (II): A Visual Approach System using BIM, In: ISARC, Proceedings of the International Symposium on Automation and Robotics in Construction, Vilnius Gediminas Technical University, Department of Construction Economics \& Property, 2017, vol.34

[22] Moradi N., Mousavi S. M., Vahdani B., An earned value model with risk analysis for project management under uncertain condi- 
tions, Journal of Intelligent \& Fuzzy Systems, 2017, 32(1), 97-113

[23] Denas S., Risk analysis using earned value: An engineering project management study. International Journal of Risk and Contingency Management (IJRCM), 2015, 4(3), 22-33

[24] Zareei A., Bagherpour M., Noori S., The Use of Earned Value Analysis in Production Control with Uncertainty Conditions, Journal of Uncertain Systems, 2011, 5(1), 21-32

[25] Acebes F., Pereda M., Poza D., Pajares J., Stochastic earned value analysis using Monte Carlo simulation and statistical learning techniques, International Journal of Project Management, 2015, 33(7), 1597-1609
[26] Pajares J., Lopez-Paredes A., An extension of the EVM analysis for project monitoring: The Cost Control Index and the Schedule Control Index, International Journal of Project Management, 2011, 29(5), 615-621

[27] Ong H. Y., Wang C., Zainon N., Developing a Quality-Embedded EVM Tool to Facilitate the Iron Triangle in Architectural, Construction, and Engineering Practices, Journal of Construction Engineering and Management, 2018, 144 (9), 04018079

[28] Ruan S.Y., Chen Y-H., A Matrix Model for Effective of Project Management, Asian Journal of Business and Management, 2017, Vol.05 Issue 02, 47-53 